Journal and Business and Tourism

\title{
The Impact of Organizational Justice and Organizational Commitment on Turnover in the Employees of Allied Bank Peshawar Region
}

\author{
JUNAID ATHAR KHAN \\ Assistant Professor Management Science S.R.H Campus Pabbi \\ Abdul Wali Khan University Mardan \\ junaid@awkum.edu.pk \\ SAIMA AFSHEEN \\ Lecturer Management Science S.R.H Campus Pabbi \\ Abdul Wali Khan University Mardan \\ Saimaafsheen@awkum.edu.pk \\ DR. SHAHID JAN \\ Associate Professor, Department of Management Sciences \\ Islamia College, Peshawar \\ shahidjan@icp.edu.pk \\ MUHAMMAD TARIQ \\ Muhammadtariq@gmail.com
}

\section{Abstract}

The study is aimed to investigate the impact of organizational justice over the organizational commitment and turnover intention perceived by the employees regarding their jobs in the Allied Bank of Peshawar region. A total of 180 employees selected from different hierarchical levels of Bank responded to the questionnaires used for the evaluation of this study. The collected data is analysed with the help of the SPSS 22.0 version, which provided the descriptive statistical analysis that further reveal means of employee's Organizational Justice with two dimension Distributive Justice and Procedural Justice of organizational commitment and turnover, i.e. reported as close to 3.0. Reliability of the study is considered as adequate because the Cronbach Alpha values were reported considerably above than the predetermined threshold of 0.70 for all the four variables of the study. Multiple regression analysis, factor analysis were also conducted to test the hypotheses of the study and as a result, it was evaluated that the two dimensions of the organizational justice, i.e. distributive and procedural have significant positive impact over the employee's job commitment and reduction in turnover of employees to other banks or other organizations. The study will help the decision makers and especially the HR executives in obtaining some better understanding of the relationship of two variables with organizational justice, so that they can formulate certain suitable strategies for the employees and organization as a whole, which in turns lead to higher level of satisfaction among employees and improve their performance as a whole. A number of limitations of this study and recommendations for the future researchers are also discussed at the end of the study.

Keywords: Organizational Commitment, organizational justice, employee turnover, Pakistan 


\section{Introduction}

One of the important factor in the establishment of the organizations are human Resource and contribution of that cannot be ignored in the social institutions where justice has the central partworking as "glue" that moivate people to work together efficiently (Bratton, John, \& Jeff, 2012). It has also beenanalysed that staff retention is considered as one of the most important aspects related to human resource challenges that faced by organization. (Agarwala \& Tanuja, 2012). Considering the importance reported by (Brayfield, Arthur, Walter \& Crockett, 2014). Positive contribution of employees also required by organization to meet organizational challenges efficiently. Due to the fast communication and globalization the turnover of employees for the organizations become the issue with other problems to provide friendly and flexible environment in order to get employees the opportunity to grow by not switching to other organization. (Bytyqi, Fisnik, Vllaznim \& Vyrtyt, 2010).

The concept of organizational commitment along with organizational justice has gained significant importance with turnover during the past few decades and part of human resource development (HRD) (Brayfield, Arthur, Walter \& Crockett, 2014) suggests justice is the fundamental concept in selection of participants for the training and development programs and the allocation of such opportunities into different regions or areas, however it has been largely recognized by the western countries, but the private sector organizations of Pakistan especially banking sector are still in their early stages of recognizing the concept of organizational justice and subsequent adaptation of systematic approaches towards turnover intention.

\subsection{Objectives of the Research}

- To measure the impact of the procedural justice on turnover intention of the employees of Allied Bank Peshawar Region

- To measure the impact of distribution justice on turnover intention of the employees of Allied Bank Peshawar Region.

- To measure the role of organizational commitment and organizational justice (procedural justice and distributive justice) in the employees of Allied Bank Peshawar Region.

\section{Literature Review}

The study is the examination of organizational justice considered as highly essential factor for influencing the organizational commitment and turnover towards their job or careers through a comprehensive literature review.

\subsection{Organizational Justice}

Organizational justice refers to the employee judgement in the form of behaviour and the resulting factors coming out from that. (Dusterhoff, Carrie, Barton , \& Jame, 2014).Its importance cannot be overlooked (Colquitt \& Jason , 2013). It is further composed of distributive, procedural and interactional justice (Mitchell \& Jonathan , 2012; Loi, Raymond, Long \& Ka , 2012; Ambrose, Maureen , Marshall, \& David , 2013).Collectively all components of justice is based on the seven procedural rules as under.

- Accuracy

- Consistency

- Ethicality 
- Work place

- Distributing Tasks

- Pay rules

- Pay Level

\subsection{Organizational Commitment}

It is considered as the bond between employees and organization in the form of experience, qualification, decision making powers, skills and abilities, workplace environment, which are directly and indirectly linked with operational functional activities (Meyer \& Smith, 2013). Furthermore (Meyer, John , Catherine , \& Smith , 2012) Suggests that it is a feeling of connection for long period and contribution of employees towards the achievement of goals.

The success, value addition, competitive business edges around the globe can be achieve by enhancing the feeling of commitment in the organization (Salleh \& Munir, 2013). OC is further divided into three types.

\subsubsection{Affective Commitment}

It is the emotional attachment, identification and involvement of people in an organization.

\subsubsection{Continuance Commitment}

It is the consideration of cost to leave organization.

\subsubsection{Normative Commitment}

It is a feeling of obligation to stay within current network of organization.

\subsection{Relationship of Justice and Commitment}

Mitchell and Jonathan (2012) Implies that the perception of justice is positively associated with OC, however (Benjamin \& Akinyemi, 2012) explains the three context of its types have their own importance with change in meaning, moreover they suggests that justice is base of social morality or moral values and individuals prefer fair procedures in unfavourable circumstances i.e. when process is perceived to be fair, individual is openly accepting all consequences related to it. In the previous literature the relationship of turnover and commitment is reported negative.

\subsection{Turnover and Relationship with Perception of Justice}

When Employees of the organization leaves voluntary/Involuntary in both of the case organization is to bear a cost of replacement by recruitment or selection. We have studied the behaviour who either involuntary or voluntary quit their job under VRS scheme in Allied Bank Peshawar region.Higher turnover have the negative sign on the good will or image of the organization but in the case of non-productive workers in the organization. (Cho \& Yoon, 2017). Turnover is regarded as critical issue and a major problem for the organizations. (Leunissen \& Joost, 2016), (Benjamin \& Akinyemi, 2012)Found that there is a direct relationship between unsatisfied employees and turnover. Justice perception and employees turnover intentions are correlated with eachother(Colquitt \& Jason, 2013) put forward the correlation between the perception of justice and turnover intentions.

\section{Methodology}

\subsection{Research Philosophy}

Data has been collected from both the primary and secondary resources; hence more consideration has been given topositivistic approach to evaluate the selected variables. The use of these models are help full to test the propose hypothesis by performing 
experiments through collected data during the questionnaires and evaluation of the research topic through critical application of the related literature and findings of past studies.

\subsection{Research Approach}

In view of the objectives of the research questionnaires are distributed among the target audience i.e. among the different categories of employees of Allied Bank Peshawar region through deductive approach to find out the problems. Based upon the empirical study the researcher used the past studies and theories to have detailed understanding of the topic area so that an informed conclusion could be obtained from the participants.

\subsection{Instrument Development}

In order to complete the study, the three set of 32 items adopted questionnaires were used by reviewing the prior literature. This 27 items questionnaire is basically divided into three categories to address the different dimension of organizational justice, organizational commitment and turnover intention. The 10 items scale measure procedural justice taken from (Loi, Raymond, Long \& Ka , 2012). To measure distributive justice 9 items adopted questionnaire of (Mitchell \& Jonathan , 2012) is used in the study. To measure the turnover intention 8 items and organizational commitment 7 items adopted set of (Cho \& Yoon, 2017) is applied by the study.The participants of the study have recorded their responses over a 5 point Likert scale ranging from "Strongly agree" at number 1 to "Strongly disagree" at number 4 . The respondents were given assurance that the information collected from you would be kept confidential from the top management of the bank and other regulatory authorities of the country.

\subsection{Research Design}

The basic purpose of this study is the analysis and measurement of impact of organizational justice over organizational commitment and turnover intention in the private sector organization Allied Bank of Pakistan so, opinion were obtained regarding the perception of employees on organizational justice and the problem of turnover in their Bank. The quantitative analysis is used the check the various hypothesis developed during the study. As it is already mention that deductive method is used to increase the reliability of study and reduce the researcher intervention at limited level.

\subsection{Sample Size and Sampling Methodology}

Population of the study is Allied Bank, but Peshawar region of the bank is taken as representative sample is for this study. The selection is based on the objective to evaluate the overall attitude and level of organizational justice of all the categories employees. The researcher used personal contacts for collection of data and distribution of questionnaire because researcher has remained the Branch Manager from 2007 till 2012. Total of 180 employees were selected randomly from different management levels throughout the region, however all the employees of the sample responded in the good manner without any invalid reason.

\subsection{Theoretical Framework Model}

The conceptual framework of the study is presented in the following figure in which the relationship of independent variables \& dependent variables portrayed in the study, i.e. on the bases of the propose model and different sub dimensions of the variables helped in development of hypothesis, which are evaluated against the data obtained from the responses to reach a conclusion over the subject matter, furthermore the model is 
composed of four variables. Independent variables are procedural justice(Loi, Raymond, Long , \& Ka , 2012) and distributive justice(Mitchell \& Jonathan , 2012) whereas organizational commitment and turnover intentions(Cho \& Yoon, 2017) are used as dependent variables. SPSS software (Pallant \& Julie , 2012)is use for data entry, processing and outcome. The main functionality of SPSS software is considered as helpful tool for practically apply demographic information, correlation analysis and multiple regression analysis model to know the actual worth of variables in the study.

$H_{1}$ : Procedural justice is negatively associated with employee turnover intention working in Allied Bank of Pakistan.

$\mathrm{H}_{2}$ : Distributive justice is negatively associated with employee turnover intention working in Allied Bank of Pakistan.

$H_{3}$ : Organizational commitment is positively associated with procedural justice in Allied Bank of Pakistan.

$\mathrm{H}_{4}$ : Organizational commitment is positively associated with distributive justice in Allied Bank of Pakistan

\section{Analysis}

\subsection{Reliability Statistics}

It is used for evaluating inner consistency among variables. The result of reliability statistics of the study are presented as followed:

\section{Table 1: Reliability Statistics}

\begin{tabular}{lll}
\hline & Cronbach's Alpha & N of Items \\
\hline Procedural Justice & .718 & 8 \\
Distributive Justice & .788 & 9 \\
Turnover Intentions & .799 & 8 \\
Organizational & .791 & 7 \\
commitment & & 70 \\
\hline
\end{tabular}

Reliability is calculated by Cronbach's Alpha and $\mathrm{N}$ of items. The value of procedural justice is calculated as 0.718 with $\mathrm{N}=10$, distributive justice is 0.788 where $\mathrm{N}=9$ and the value of turnover intentions is calculated as 0.799 with $\mathrm{N}=8$ and similarly 0.791 where $\mathrm{N}=7$ considered good to apply further statistical tests.

Table 2: Demographic Information

\begin{tabular}{|c|c|c|}
\hline Demographic Information & Frequency & Percentage \\
\hline \multicolumn{3}{|l|}{ Gender } \\
\hline Male & 92 & 51.11 \\
\hline Female & 88 & 48.89 \\
\hline \multicolumn{3}{|l|}{ Marital Status } \\
\hline Married & 125 & 69.44 \\
\hline Single & 55 & 30.55 \\
\hline \multicolumn{3}{|l|}{ Age } \\
\hline 29 and Below & 52 & 28.89 \\
\hline 30 to 39 years & 62 & 34.44 \\
\hline 40 to 49 Years & 27 & 15.00 \\
\hline
\end{tabular}




\begin{tabular}{|c|c|c|}
\hline 50 and above Years & 39 & 21.67 \\
\hline \multicolumn{3}{|l|}{ Educational Level } \\
\hline Secondary & 10 & 5.55 \\
\hline Diploma & 33 & 18.33 \\
\hline Bachelor Degree & 125 & 69.44 \\
\hline Postgraduate & 12 & 6.67 \\
\hline \multicolumn{3}{|l|}{ Job Tenure } \\
\hline 5 and below & 50 & $29 \%$ \\
\hline 6 to 10 years & 17 & $10.00 \%$ \\
\hline 11 to 15 year & 45 & $26.10 \%$ \\
\hline 16 to 20 years & 60 & $35 \%$ \\
\hline \multicolumn{3}{|l|}{21 and above } \\
\hline \multicolumn{3}{|c|}{$\begin{array}{l}\text { Years with current } \\
\text { organization }\end{array}$} \\
\hline 3 to 5 years & 12 & 6.667 \\
\hline 6 to 10 Years & 26 & 14.44 \\
\hline 11 to 15 years & 42 & 23,33 \\
\hline 16 and above years & 38 & 21.11 \\
\hline \multicolumn{3}{|l|}{ Annual Income } \\
\hline 25000 and below & 40 & 22.22 \\
\hline 25001 to 50000 & 40 & 22.22 \\
\hline 50001 to 100000 & 18 & 10.00 \\
\hline 100001 to 150000 & 45 & 24.00 \\
\hline 150001 and Above & 37 & 20.55 \\
\hline \multicolumn{3}{|l|}{ Job Level } \\
\hline Senior Management & 52 & 28.89 \\
\hline Middle Management & 19 & 10.55 \\
\hline Supervisory & 47 & 26.11 \\
\hline Others & 62 & 34.44 \\
\hline
\end{tabular}


Table 4: Procedural Justice

Component matrix value before and after rotation procedural justice

\begin{tabular}{|c|c|c|c|c|}
\hline $\begin{array}{l}\text { Procedural } \\
\text { Justice }\end{array}$ & $\begin{array}{l}\text { Component } \\
\text { rotation) }\end{array}$ & Matrix (before & $\begin{array}{l}\text { Component } \\
\text { rotation) }\end{array}$ & Matrix (after \\
\hline P01 & 1 & 2 & 1 & 2 \\
\hline P02 & 0.717 & 0.359 & 0.254 & 0.286 \\
\hline P03 & 0.516 & 0.546 & 0.333 & 0.438 \\
\hline P04 & 0.615 & 0.654 & 0.983 & 0.623 \\
\hline P05 & 0.719 & 0.453 & 0.429 & 0.865 \\
\hline P06 & 0.782 & 0.889 & 0.52 & 0.729 \\
\hline P07 & 0.755 & 0.022 & 0.782 & 0.157 \\
\hline P08 & 0.882 & 0.551 & 0.311 & 0.863 \\
\hline P09 & 0.354 & 0.224 & 0.536 & 0.543 \\
\hline P10 & 0.845 & 0.211 & 0.483 & 0.28 \\
\hline
\end{tabular}

Extraction method: Principal component analysis and the significant value is $>\mathbf{1 . 0 0}$.

Table 5: Distributive Justice

\begin{tabular}{|c|c|c|c|c|}
\hline \multirow{2}{*}{$\begin{array}{l}\begin{array}{l}\text { Distributive } \\
\text { Justice }\end{array} \\
\text { D11 }\end{array}$} & \multicolumn{2}{|c|}{$\begin{array}{l}\text { Component } \\
\text { Matrix(before } \\
\text { rotation) } \\
\end{array}$} & \multicolumn{2}{|c|}{$\begin{array}{l}\text { Component } \\
\text { Matrix(after } \\
\text { rotation) } \\
\end{array}$} \\
\hline & 1 & 2 & 1 & 2 \\
\hline $\mathrm{D} 12$ & 0.615 & 0.654 & 0.983 & 0.623 \\
\hline D13 & 0.755 & 0.022 & 0.782 & 0.157 \\
\hline D14 & 0.882 & 0.551 & 0.311 & 0.863 \\
\hline D15 & 0.516 & 0.546 & 0.333 & 0.438 \\
\hline D16 & 0.615 & 0.654 & 0.983 & 0.623 \\
\hline D17 & 0.845 & 0.211 & 0.483 & 0.28 \\
\hline D18 & 0.516 & 0.546 & 0.333 & 0.438 \\
\hline D19 & 0.615 & 0.654 & 0.983 & 0.623 \\
\hline D20 & 0.755 & 0.022 & 0.782 & 0.157 \\
\hline
\end{tabular}




\section{Hypothesis Testing}

\section{Table 6: Correlation Analysis}

The result of hypothesis testing is presented as followed:

\begin{tabular}{|c|c|c|c|c|c|}
\hline & & $\begin{array}{l}\text { Procedural } \\
\text { Justice }\end{array}$ & $\begin{array}{l}\text { Distributive } \\
\text { Justice }\end{array}$ & $\begin{array}{l}\text { Organizational } \\
\text { Commitment }\end{array}$ & $\begin{array}{l}\text { Turnover } \\
\text { Intention }\end{array}$ \\
\hline \multirow{4}{*}{$\begin{array}{l}\text { Procedural } \\
\text { Justice }\end{array}$} & Pearson & 1 & $.591^{* *}$ & $.521^{* *}$ & $-.694^{* *}$ \\
\hline & Correlation & & & & \\
\hline & $\begin{array}{l}\text { Sig. } \\
\text { tailed) }\end{array}$ & & .000 & .000 & .000 \\
\hline & $\mathrm{N}$ & 180 & 180 & 180 & 180 \\
\hline \multirow{2}{*}{$\begin{array}{l}\text { Distributive } \\
\text { Justice }\end{array}$} & Pearson & $.591^{* * *}$ & 1 & $.636^{* * *}$ & $-.586^{* *}$ \\
\hline & $\begin{array}{l}\text { Correlation } \\
\text { Sig. (2- } \\
\text { tailed) }\end{array}$ & .000 & & .000 & .000 \\
\hline \multirow[t]{3}{*}{$\begin{array}{l}\text { Organizational } \\
\text { Commitment }\end{array}$} & $\begin{array}{l}\mathrm{N} \\
\text { Pearson } \\
\text { Correlation }\end{array}$ & $\begin{array}{l}180 \\
.521^{* *}\end{array}$ & $\begin{array}{l}180 \\
.636^{* * *}\end{array}$ & $\begin{array}{l}180 \\
1\end{array}$ & $\begin{array}{l}180 \\
-.647^{* *}\end{array}$ \\
\hline & $\begin{array}{l}\text { Sig. } \\
\text { tailed) }\end{array}$ & .000 & .000 & & .000 \\
\hline & $\mathrm{N}$ & 180 & 180 & 180 & 180 \\
\hline \multirow[t]{3}{*}{$\begin{array}{l}\text { Turnover } \\
\text { Intention }\end{array}$} & $\begin{array}{l}\text { Pearson } \\
\text { Correlation }\end{array}$ & $-.694^{* *}$ & $-.586^{* *}$ & $-.647^{* *}$ & 1 \\
\hline & $\begin{array}{l}\text { Sig. } \\
\text { tailed) }\end{array}$ & .000 & .000 & .000 & \\
\hline & $\mathrm{N}$ & 180 & 180 & 180 & 180 \\
\hline
\end{tabular}

\subsection{Hypothesis Testing}

The process of hypothesis testing model is referring to the technique used for the evaluation and measuring the relationship between the two or more independents variables correlated with dependent variable. It is clear from the correlation table that there is positive association among Procedural justice and organizational commitment.

The Second hypothesis is about the distributive justice whichis negatively associated with employee turnover intention working in bank. The correlation value between distributive justice and employee turnover intention is 0.586 which is highly significant and shows negative relationship.

Third research hypothesis is about organizational commitmentwhich is positively associated and highly significant with procedural justice at the level of 0.521 . Furthermore, the forth hypothesis indicates positive correlation among organization commitment and distributive justice which is defended by the finding of correlation analysis. The correlation value of 0.636indicates that the higher the perception distributive justice of employees the higher would be commitment level. Hence, all the hypotheses are approved and supported by theoretical framework model.

\subsection{Regression Analysis}

The process of multi regression analysis modeldetermines, generates and evaluates the equation for describing the statistical relationship between one or more predictor variables and the response variables used in this study 
Table 7: Model Summary ${ }^{\mathrm{a}}$

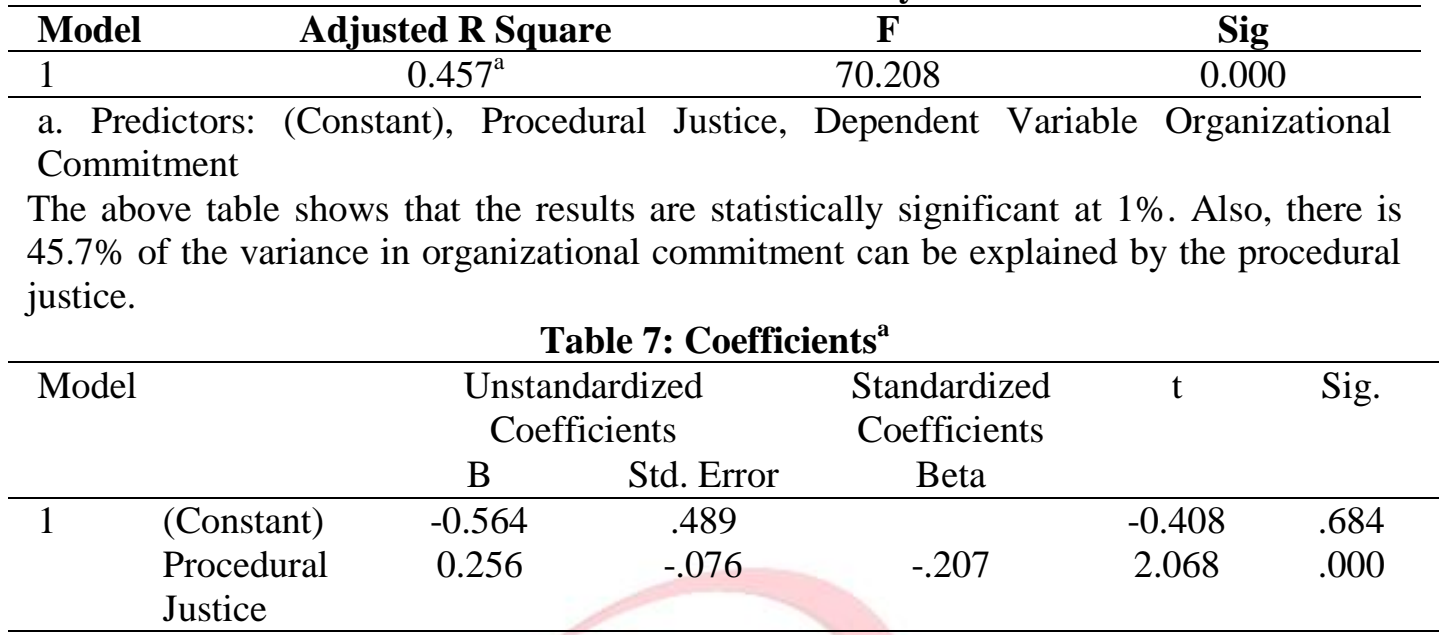

a. Dependent Variable: Organizational Commitment

Table 8: Model Summary ${ }^{\mathrm{a}}$

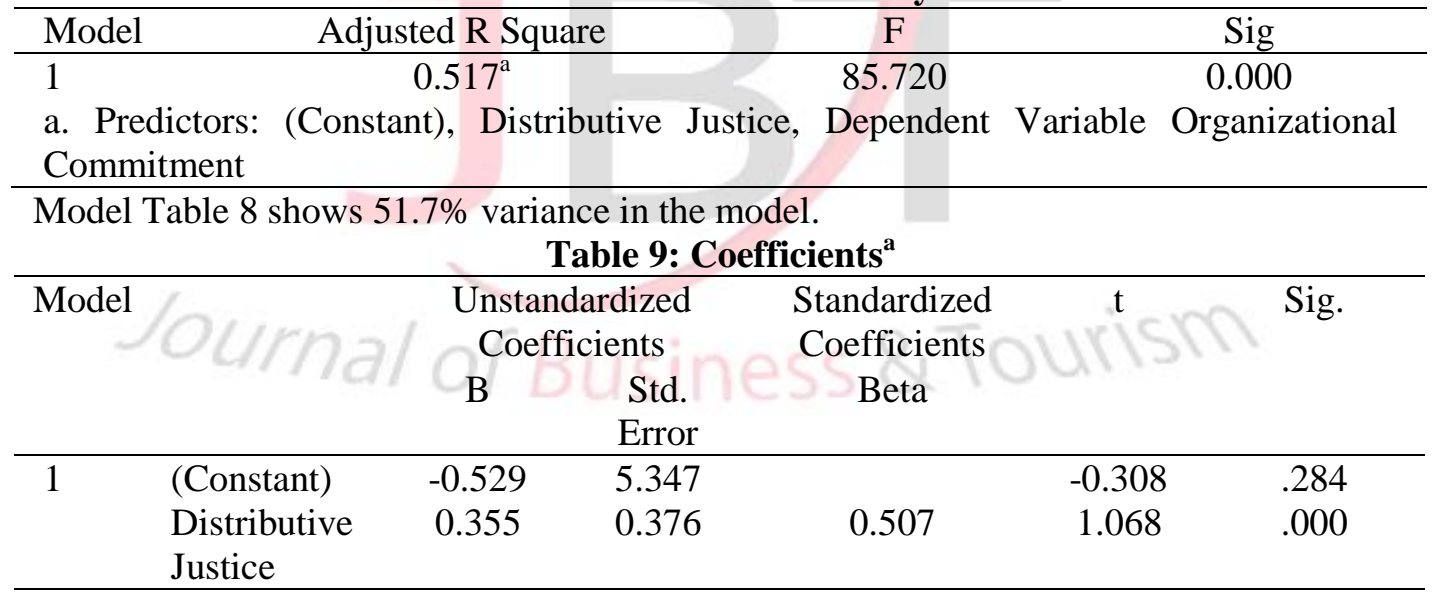

a. Dependent Variable: Organizational Commitment

Second predicator is distributive justice having beta value is 0.529 . It has been observed that these variables are considered as good for further overcome the problem of employee turnover intention from Allied Bank of Pakistan.

Table 10: Model Summary ${ }^{a}$

\begin{tabular}{lccc}
\hline Model & Adjusted R Square & F & Sig \\
\hline 1 & 0.264 & 45.21 & 0.000 \\
\hline
\end{tabular}

a. Predictors: (Constant), Procedural Justice, Dependent Variable Turnover intention The above table was conducted to investigate the employees' perception od procedural justice and turnover intention in the bank. The adjusted $\mathrm{R}^{2}$ shows that $26.4 \%$ of the variance in turnover intention can be explained by the perception of procedural justice in organization while the unexplained variance is $73.6 \%$. 
Table 11: Coefficients ${ }^{\mathrm{a}}$

\begin{tabular}{llccccc}
\hline Model & & \multicolumn{2}{c}{ Unstandardized } & Standardized & t & Sig. \\
& & Coefficients & Coefficients \\
& & B & Std. & Beta & & \\
& & Error & & & \\
\hline 1 & (Constant) & 19.115 & 0.529 & & 21.108 & 0.000 \\
& Procedural & -0.556 & 0.336 & -0.607 & -9.068 & 0.000 \\
& Justice & & & & & \\
\hline
\end{tabular}

a. Dependent Variable: Turnover Intention

The equation to identify the relationship among the defined variables is:

Turnover intention $(\mathrm{y})=19.115-0.556 \times$ Procedural Justice:

Table 12: Model Summary ${ }^{a}$

\begin{tabular}{lccc}
\hline Model & Adjusted R Square & F & Sig \\
\hline 1 & 0.354 & 135.00 & 0.000 \\
\hline
\end{tabular}

a. Predictors: (Constant), Distributive Justice, Dependent Variable Turnover intention The table 12 indicates there is $35.4 \%$ variance in turnover intention can be explained by the distributive justice whereas $64.6 \%$ of the variance in unexplained.

\begin{tabular}{|c|c|c|c|c|c|c|}
\hline \multirow{2}{*}{\multicolumn{2}{|c|}{ Model }} & \multicolumn{2}{|c|}{$\begin{array}{l}\text { Unstandardized } \\
\text { Coefficients } \\
\text { B Std. }\end{array}$} & \multirow{2}{*}{$\begin{array}{c}\text { Standardized } \\
\text { Coefficients } \\
\text { Beta }\end{array}$} & \multirow[t]{2}{*}{$\mathrm{t}$} & \multirow[t]{2}{*}{ Sig. } \\
\hline & & B & $\begin{array}{l}\text { Std. } \\
\text { Error }\end{array}$ & & & \\
\hline 1 & $\begin{array}{l}\text { (Constant) } \\
\text { Distributive } \\
\text { Justice }\end{array}$ & $\begin{array}{l}18.325 \\
-0.426\end{array}$ & $\begin{array}{c}.819 \\
-.526\end{array}$ & -0.257 & $\begin{array}{c}19.532 \\
- \\
12.012 \\
\end{array}$ & $\begin{array}{c}0.000 \\
.000\end{array}$ \\
\hline
\end{tabular}

a. Dependent Variable: Turnover Intention

Second predicator is distributive justice having beta value is 18.325 at $1 \%$ level of significance. It has been observed that these variables are considered as good for further overcome the problem of employee turnover intention from Allied Bank of Pakistan. Based on the results it clear organizational justice can be help full tool to retain employee with in the bank along with other good management policies to increase profitability of the bank as whole

\section{References}

Agarwala, \& Tanuja, (2012). Strategic human resource management. Arth Anvesan 71.

Ambrose, M., Marshall, L. S. \& David, (2013). Trickle-down effects of supervisor perceptions of interactional justice A moderated mediation approach.. Journal of Applied Psychology, 98(4), 678.

Bakhshi, A., Kuldeep, K., \& Ekta, R. (2012). Organizational justice perceptions as predictor of job satisfaction and organization commitment. International journal of Business and Management Vol.4(9), 145.

Benjamin, \& Akinyemi, (2012). Human resource development climate as a predictor of citizenship behaviour and voluntary turnover intentions in the banking sector. International Business Research Vol. 5(1), 110. 
Bratton, J., \& Jeff, G. (2012). Human resource management. theory and practice. Palgrave Macmillan.

Brayfield, A. H., Walter , H., \& Crockett. (2014). Employee attitudes and employee performance. Psychological bulletin, Vol.52(5), 369.

Bytyqi, F., Vllaznim, R. \& Vyrtyt, H. (2010). Work stress, job satisfaction and organizational commitment among public employees before privatization. European journal of social sciences, Vol.18(1), 156-162.

Cho, \& Yoon, N. (2017). The Role of Emotions on Frontline Employee Turnover Intentions. Journal of Marketing Theory and Practice, Vol. 25(1), 57-68.

Colquitt, \& Jason, A. (2013). Justice at the millennium a meta-analytic review of 25 years of organizational justice research. Journal of applied psychology, Vol. 86(3), 425.

Dusterhoff, C. J., Barton, C., \& Jame. (2014). The effects of performance rating, leadermember exchange, perceived utility, and organizational justice on performance appraisal satisfaction Applying a moral judgment perspective. Journal of Business Ethics, Vol. 119(2), 265-273.

Leunissen, \& Joost. (2016). Organizational nostalgia lowers turnover intentions by increasing work meaning the moderating role of burnout. Journal of Management.

Loi, R., Long, W. L. \& Ka, W. C. (2012). Coping with job insecurity The role of procedural justice, ethical leadership and power distance orientation. Journal of Business Ethics, Vol. 108(3), 361-372.

Meyer, J. \& Smith, C. (2013). HRM Practices and Organizational Commitment Test of a Mediation Model. Canadian Journal of Administrative sciences, 17(4), 319-331.

Meyer, John, P., Catherine, A., \& Smith. (2012). HRM practices and organizational commitment Test of a mediation model. Canadian Journal of Administrative Sciences, Vol.17(4), 319.

Mitchell, \& Jonathan, I. (2012). The role of perceived organizational support, distributive justice and motivation in reactions to new information technology. Computers in Human Behavior, Vol. 28(2), 729-738.

Pallant, \& Julie . (2012). SPSS Survival Manual. A step by step guide to data analysis using SPSS.

Salleh, \& Munir. (2013). Fairness of performance appraisal and organizational commitment. Asian Social Science, 9 (2), 121. 